\title{
A TEATRALIDADE PARA ALÉM DOS PALCOS NA AVENIDA DO CARNAVAL
}

Ana Luiza da Luz (Udesc)

A teatralidade está dentro e fora do teatro. Indo muito além dos campos artísticos, cobre significativa gama de manifestações culturais, abarcando, assim, o carnaval. Neste artigo observo quais são os recursos utilizados no processo de construção conceitual e visual nos desfiles de carnaval como possível estratégia de suscitar a identificação da teatralidade no espectador.

TEATRALIDADE; ESCOLAS DE SAMBA; RECEPÇÃO.

LUZ, Ana Luiza da. A teatralidade para além dos palcos na avenida do carnaval. Textos escolhidos de cultura e arte populares, Rio de Janeiro, v.10, n.2, p. 127-150, nov. 2013. 


\section{THEATRICALITY BEYOND THE STAGE IN CARNAVAL'S AVENUE}

Ana Luiza da Luz (Udesc)

Theatricality is both inside and outside the theatre. Far beyond artistic fields, it encompasses a great variety of cultural manifestations such as carnival. This article aims at analysing the resources used in the process of visual and conceptual construction of carnival parades as possible strategies to arouse the identification of theatricality within the spectator.

THEATRICALITY; SAMBA SCHOOLS; RECEPTION.

LUZ, Ana Luiza da. A teatralidade para além dos palcos na avenida do carnaval. Textos escolhidos de cultura e arte populares, Rio de Janeiro, v.10, n.2, p. 127-150, nov. 2013. 
O carnaval das escolas de samba é costumeiramente chamado de Ópera de Rua no meio carnavalesco. Essa expressão é compartilhada por diversos profissionais das agremiações e por vários estudiosos do tema. A mistura do vocabulário e do conhecimento erudito-acadêmico com a espontaneidade e intuição dos sambistas dos morros cariocas começou a partir da entrada dos profissionais da Escola de Belas Artes do Rio de Janeiro no carnaval, na década de 1960. Desde então o carnaval tornou-se cada vez mais uma "ópera-balé ambulante", como conceituam Valença e Valença (1981), e acabou por deixar de ser mera brincadeira de rua para se tornar uma linguagem artística. Esse movimento em direção à constituição de uma linguagem artística encontrou ao longo da história do carnaval, e ainda encontra, muita resistência por parte dos puristas ligados à tradição e ao que chamam de "essência do carnaval".

O desenvolvimento plástico que os desfiles ganharam com a entrada de artistas formados na Escola de Belas Artes foi um divisor de águas na trajetória artística do carnaval das escolas de samba que, porém, não se permitiu estacionar aí. Neste século XXI houve nova revolução, com desfiles cada vez mais teatralizados e conceitualmente elaborados, a partir, principalmente, do trabalho do carnavalesco Paulo Barros, que vem exercendo forte influência em muitas escolas. Com isso, novamente se reconduziu essa linguagem para novos caminhos expressivos e estéticos.

Por mais que essa forma de desfile venha conquistando a cada ano a simpatia do público e da crítica especializada, muitos tradicionalistas a criticam, alegando que o carnaval deixa ano a ano de ser uma festa para se tornar um espetáculo, fugindo de sua "espontaneidade" e das convenções originais. O programa do Carnaval de 1976 do GRES Imperatriz Leopoldinense, entretanto, aponta que o "assassinato" desse carnaval "espontâneo" e "convencional" vem sendo anunciado pelos tradicionalistas há muito tempo. Tanto que essa escola, rebatendo as críticas conservadoras, defende as inovações e esclarece sua concepção de escola de samba:

O gênero Escola de Samba, não só na sua autonomia estética, como por influências históricas e socioeconômicas, mas também por ser uma "obra aberta", na terminologia de Umberto Eco, influencia e é influenciável. Não podia, portanto, estagnar em formas imutáveis, hirtas. Evoluiu, isto é, sacrificou características originais e adquiriu padrões novos e valores enriquecidos. Não adianta discutir. $\mathrm{O}$ substantivo é o mesmo. O que houve foi acréscimo de adjetivos, nem sempre felizes ou cabíveis. Esse processo de mutação estética é irreversível. Uma Escola de Samba na sua essência, é um Auto; desfilando, é uma Ópera de Rua. Não pretende ir além do lúdico, com 
sua exuberância plástica, barroca ${ }^{1}$ (Programa do desfile do GRES Imperatriz Leopoldinense, 1976).

Desde a criação das escolas de samba, no Rio de Janeiro, no final da década de 1930, provenientes dos ranchos e cordões, ${ }^{2}$ houve quem desse um passo adiante, reinventando uma convenção, como também houve quem bradasse, injuriado, contra esse passo, defendendo a convenção. No ano seguinte, no entanto, muitos dariam o mesmo passo, tornando a invenção do ano anterior uma nova convenção. E assim o carnaval foi-se dialogicamente autoconstruindo, permitindo-se ser uma obra aberta que tem permissão para reinventar-se, retornando a seu passado para buscar novas referências para o futuro.

A questão da convenção é muito conhecida em todos os movimentos artísticos. A polêmica não é exclusividade do carnaval, mas perpassa toda a arte e cultura. Ser vanguarda nunca foi algo aceito por todos, e talvez nunca venha a ser, embora seja inegável sua importância para manter viva e pulsante qualquer expressão artística e cultural. Devemos perceber, conforme destaca Schechner (2000), que o que no passado foi vanguarda é hoje hegemônico e amanhã poderá ser esquecido, para, assim, nos permitir aceitar conhecer o novo, certos de que o cabível permanecerá; o que não o for se autoabortará, como afirmava o GRES Imperatriz Leopoldinense em 1976.

Fato é que o carnaval das escolas de samba nunca foi igual desde seu aparecimento, nunca foi algo imóvel com regras fixas de como fazer. Ao contrário, sempre foi expressão da criatividade, ousadia e superação. Num movimento constante, ano após ano, criaram-se os desfiles, inventando algo aqui, imitando algo acolá, e nessa dinâmica chegando até nossos dias. Assim, nos damos conta de que o carnaval nunca mais será o mesmo, simplesmente porque nunca foi o mesmo.

O que se percebe hoje é tendência cada vez maior à espetacularidade, utilizando-se mais e mais recursos dramáticos, apostando em encenações e coreografias que evidenciam crescentemente a teatralidade.

\section{A TEATRALIDADE NA AVENIDA}

O conceito de teatralidade é variável. É questão não fechada na teoria teatral, que no decorrer dos anos ganhou interpretações distintas e mesmo opostas. Se recorrermos à literatura do tema, encontraremos a definição de Nikolai Evreinov (1879-1953). Defendendo um "instinto teatral”, Evreinov afirma que a teatralidade é o instinto humano de transfigurar o real, de se opor às imagens recebidas, transformando as aparências naturais em algo novo, distinto. Sendo um ins- 
tinto humano, a teatralidade está além do próprio teatro, está na vida cotidiana. Evreinov defende, então, a ideia de que a teatralidade, bem como o teatro, é préestética, independente e anterior a qualquer percepção ou senso estético. Aqui é evidente o caráter sociológico e antropológico do termo, mais voltado para o estudo do comportamento social humano do que para o objeto propriamente artístico.

Ligada à ideia de exagero, artificialidade, encontramos a definição de Vsevolod Meierhold (1874-1940) para a teatralidade. Desenvolvendo uma proposta cênica nova, que contrariava os padrões realistas do início do século XX, o encenador russo buscou o que ele chamou de teatro teatral. Para isso, Meierhold baseou seu trabalho no grotesco, procurando reinventar, assim, a realidade, representá-la utilizando-se de outros referenciais estéticos para provocar uma atitude diferente no espectador frente ao espetáculo e com isso "alterar a percepção do espectador, tirando-o do plano do conhecido e esperado e instalando-o em outro, que ele não imaginava, Meyerhold provoca um deslocamento constante, jogando com contradições agudas e gerando uma espécie de surpresa no público" (NASPOLINI, 2005, p. 51).

Partindo da perspectiva de Meierhold, cria-se a ideia de que há um "teatro não teatral", que nem sempre a teatralidade está presente, que ela se opõe frontalmente à realidade. E essa oposição entre teatralidade e realidade sustentará boa parte das concepções que encontramos desse termo, ligando-o diretamente à ideia de exagero, artifício e artificialidade. Podemos notar essa noção em Ubersfeld (2005) ao argumentar que a teatralidade nega a realidade do acontecimento, apelando para a inverossimilhança e atentando contra o bom-senso. Partindo dessa noção de teatralidade é preciso desnaturalizar, artificializar para romper com qualquer possibilidade de ilusão, revelando a realidade teatral ao oporse à realidade dos acontecimentos. Féral (2003, p. 56) ao referir-se à teatralidade proposta por Meierhold, afirma que:

Meierhold quer que o teatro não seja tautológico com a realidade, não seja redundante. Quer enfatizar sua autonomia e, para tanto, sua especificidade. O teatro deve desenvolver sua própria forma, tem que converter-se em uma arte própria. É por isso que Meierhold fala de um teatro teatral (...) o teatro teatral se opõe ao realismo (...) Segundo ele, há uma teatralidade falsa, a que tenta copiar a realidade. Ao contrário, ele destaca a necessidade de uma teatralidade absoluta. ${ }^{3}$

A crítica que Féral faz a essa ideia de teatralidade defendida por Meierhold é a de ser muito fechada, ligada somente à estética e à natureza da representa- 
ção, em oposição à proposição de Evreinov, que ela também critica por ser muito ampla, desqualificando o termo, pois, já que tudo é teatralidade, nada o é, segundo a autora. Quanto a essa ideia de que a teatralidade não está presente apenas no teatro, Féral aproxima-se da concepção de Evreinov, afirmando que também está presente em outros campos artísticos e até mesmo não artísticos. Porém, delimita seu espaço de atuação, diferente de Evreinov, ao sustentar que seu alcance está nas performances estéticas em geral.

Féral afirma a necessidade de despojarmo-nos da ideia de artificialidade, de oposição à realidade e "sair de uma estrutura binária, em que as palavras se opõem como uma dicotomia (...) teatralidade de um lado e realidade do outro"4 (p. 11). Enquanto Meierhold afirmou que havia um "teatro que era teatral" e outro que não o era, que em alguns tipos de teatro a teatralidade está presente e em outros não, Féral vai declarar que a teatralidade sempre está presente no teatro. Sendo um fenômeno de recepção, a partir do momento em que o espectador tem consciência de que assiste a uma representação, a teatralidade está presente para ele. O que difere é se a teatralidade está evidenciada ou não, e não se há ou não há teatralidade como propunha o encenador russo.

Em que consiste, porém, a diferença da visão de Féral para a de Evreinov e a de Meierhold, de fato? A diferença está no entendimento de onde reside a teatralidade. Enquanto Evreinov e Meierhold defendem que a teatralidade está no objeto, Féral afirma que também está nos olhos de quem vê, nos olhos de quem reconhece uma intenção de teatralidade ou então projeta a teatralidade sobre algo que vê. A teatralidade, portanto, é também um fenômeno da recepção e não apenas do objeto artístico em questão; sua leitura "desconstrói, decodifica e constrói um objeto que o sujeito observa"5 (FÉRAL, 2003, p. 16).

Acredito ser esse o aspecto fundamental da concepção de Féral quanto à teatralidade. Durante muitos anos esse termo foi estudado como sendo uma característica, inerente ao objeto (corpo, espaço, etc.), atribuindo-se a ele um valor intrínseco, uma natureza. É como se o objeto comportasse por si só uma característica teatral, independente de qualquer concepção exterior a ele. Porém, com os estudos, ainda recentes, sobre a recepção, a perspectiva se altera, e o espectador torna-se alvo dos estudos teatrais. Percebemos, então, que o valor que julgamos que algo tenha, na verdade, é o valor que lhe atribuímos, ou seja, são nosso olhar e nosso juízo que agregam valores ao objeto.

Quanto à recepção, Canclini (1980) afirma que a percepção estética depende da intervenção do sujeito que percebe, mesmo que alguns objetos possuam maior ductilidade para suscitar experiências estéticas, pois tanto o observador quanto o objeto estão determinados por um sistema de convenções que são 
históricas e sociais. Segundo Canclini o caráter estético não está propriamente na essência do objeto, mas no modo de relação dos homens com ele, variando de acordo com a cultura, a época e até mesmo a classe social. Nessa mesma perspectiva, Féral (2003, p. 77) sustenta que o reconhecimento da teatralidade irá depender do contexto, pois "um comportamento julgado muito teatral numa cultura não é necessariamente em outra". ${ }^{6}$ Assim, a teatralidade é percepção dependente de um ponto de vista, é uma perspectiva pessoal/social.

Então, se a teatralidade, como vimos, não é algo dado previamente, se não é natural ao objeto, se é uma construção do espectador, onde está a parcela de responsabilidade do artista nessa construção? Nesse sentido, Féral considera que a teatralidade obedece a duas condições para emergir. A primeira se refere à intenção do artista/performer; ${ }^{7}$ no reconhecimento dessa intenção, o espectador modifica seu olhar e passa a "semiotizar" tudo o que rodeia o ato que ele lê como teatral. A segunda condição independe do objeto observado, pois aqui o espectador julga reconhecer uma duplicidade da situação e uma suposta intenção, e, assim, lança sobre ela a teatralidade. Na primeira condição, fica clara a intenção do artista/performer de criar um espaço de representação, de ficção, pois esse espaço é fundamental para que o espectador reconheça a natureza espetacular que a ele se confere. $\mathrm{O}$ artista, então, é responsável por criar essa expectativa de representação, para que o espectador possa converter em signo cada elemento que percebe. Dessa forma, a teatralidade é prevista pelos criadores do espetáculo (atores, cenógrafo, diretores, etc.) em seu processo de criação, o que permite a manipulação do uso dos objetos, das energias, de tal forma que seja induzido no espectador o reconhecimento da intenção de representar algo e que, dessa forma, atraia o olhar do espectador e o leve a fixar os olhos. Nesse caso, que elemento constitutivo da obra intervém na teatralidade? Féral afirma que o reconhecimento da natureza mimética é determinante na teatralidade. Podemos dizer, então, que é na escolha e na manipulação mimética que o artista prevê o reconhecimento da teatralidade, e sua função é a de preparar um ambiente, uma situação para que a teatralidade seja construída, junto com o público.

Relacionada, então, à recepção, a teatralidade opera no campo do fictício, utilizando-se de recursos da "mentira" e da ilusão para nos conduzir além dos limites do real. O que regula a estrutura entre o real e o fictício é o jogo empreendido pelos atores e compreendido pelos espectadores. Dessa forma, a teatralidade se faz presente quando há o reconhecimento por parte do espectador da intenção mimética, do jogo de imitação e "mentira". Portanto, o que evidencia a teatralidade é o procedimento mimético utilizado. Tanto mais mimético, menos evidente; tanto menos mimético, mais evidente se faz a teatralidade. 
A ideia de mímesis como reformulação, recriação do real vem desde Aristóteles, contrariando a ideia platônica de cópia imperfeita da realidade. A visão aristotélica da mímesis afirma que não se trata de mera imitação (cópia) do real, mas sim de imitação idealizada, sendo a arte responsável por ir além do que a natureza foi incapaz de criar. Féral observa que esse conceito de mímesis pode ter dois sentidos, um que se refere à representação da realidade e outro que diz respeito à livre expressão da realidade, caso em que a mímesis não é imitativa, mas sim ativa ou produtiva. Neste último caso há sim uma base na mímesis imitativa, porém aqui é menos evidente. Seguindo essa perspectiva, a mímesis, segundo Féral, pode ser restrita ou geral. A restrita, ligada ao primeiro sentido, se ocupa de representar a realidade muito perto do que ela é, sem vazão ao lúdico e à fantasia. Já a geral é a mímesis ativa, produtiva, uma livre expressão da realidade. Nesse caso a realidade é suplementada de outros elementos e leituras, o que acaba por criar outra realidade, convertê-la numa realidade em si mesma. A mímesis geral é própria da teatralidade, mesmo que na restrita também possa haver teatralidade, porém de forma mais sutil e menos perturbadora.

A mímesis, então, pode ser desde uma imitação, até uma tradução, desconstrução e construção de nova realidade em cena. A desconstrução é própria da mímesis geral, que pressupõe a ficção e a realidade. Em sua teoria literária sobre a ficção, Iser (1999, p. 68) afirma que "o fictício é caracterizado por uma travessia de fronteiras entre os dois mundos que sempre inclui o mundo que foi ultrapassado e o mundo-alvo que se visa". Portanto, não há dicotomia entre ficção e realidade na mímesis, como também não há na teatralidade, visto que ela ocorre no reconhecimento por parte do espectador de uma ficção a ele apresentada, no conhecimento prévio da realidade representada. Ao contrário, não há identificação da mímesis. A ficção se autoevidencia ao apresentar a mímesis em si, ou seja, a simulação evidente, num ato consciente.

Como já mencionado, o reconhecimento da teatralidade pressupõe jogo, um acordo entre atores e espectadores. Pressupõe um caráter espetacular, uma consciência da representação; o espectador sempre percebe a dualidade do que Ihe é apresentado (FÉRAL, 2003, p. 30). O ator ao representar, fingir, fornece uma moldura ao espectador do que deve ser capturado no espetáculo. Nesse jogo, o espectador também é um jogador, que capta todo o processo, observa as transformações do objeto, joga com seu próprio olhar ao observar no mesmo enquadramento realidade e ficção, processo e produto, e confronta-os para então construir um sentido, que Ihe será único e próprio. Quando o espectador identifica a teatralidade é porque identifica "no ator um jogo de fricções entre códigos e flu- 
xos, entre simbólico e semiótico, entre caos e ordem com os quais o ator atua"8 (p. 45).

Então, podemos concluir que pode ser o ator, por meio do uso que faz de seu corpo, de sua expressividade, bem como dos objetos, que torna a teatralidade visível pelo espectador. Se ele não criasse meios, um espaço fictício, através de sua representação, a possibilidade de teatralidade seria dificilmente percebida. Portanto, o reconhecimento da mímesis e a identificação dos elementos expressivos do espetáculo são resultados da relação entre as estratégias do texto espetacular, ${ }^{9}$ de como o espetáculo é estruturado para propor uma possível leitura, e as competências perceptivas do espectador.

A teatralidade, porém, não está só na representação dos atores, está também no espaço, a partir do momento em que esse apresenta caráter espetacular. Féral afirma que há uma teatralidade latente quando há intenção de representação. Dessa forma, a teatralidade não pressupõe atores, podendo existir mesmo sem eles, como também a narrativa ou a ficção não são imprescindíveis, pois o espectador converte os elementos que observa, ainda que soltos, em signos assim que compreende e os vê como componentes de uma representação.

Para definir o espaço propício à teatralidade, Féral toma emprestada a denominação espaço potencial, de Winnicott, sendo esse espaço, para ela, o da convenção, um lugar de segurança para o ator, pois é o lugar da representação, que o separa das noções de tempo e espaço da realidade. Esse espaço, como a teatralidade, está nos olhos do espectador, ou melhor, é um espaço simbólico, presente na mente de quem observa. E é esse espaço que serve de base para a realização da mímesis, pois o espectador necessita desse espaço para ler a teatralidade presente. Ao contrário não a identificaria e, dessa forma, só conseguiria perceber a realidade. Como afirma Féral (2003, p. 43), "se o espaço potencial do ator e do espectador não se encontram, se não se reconhecem, não há teatro", ${ }^{10}$ ou seja, é necessário um acordo prévio, dado por meio das convenções conhecidas pelo espectador do fazer teatral, um jogo de aceitação entre atores e espectadores.

Seguindo a perspectiva sobre a teatralidade exposta por Féral, que a afirma presente nas performances estéticas em geral, me proponho então a buscála nos desfiles das escolas de samba. Se, de acordo com Féral, a teatralidade é reconhecida e/ou criada pelo espectador, sendo uma perspectiva pessoal/social, então, o que designarei aqui como teatral será a partir de meus parâmetros estéticos, culturais e sociais que nortearam minha leitura do espetáculo. Dessa forma, o que me interessa não é a busca ou a comprovação de uma teatralidade no evento carnavalesco, mas, sim, observar que mecanismos expressivos são utilizados pelos criadores (carnavalescos, performers, desfilantes, etc.) para que o es- 
pectador fixe seu olhar no espetáculo. Busco compreender como as energias, os corpos e os objetos são manipulados para criar esse espaço da teatralidade a que Féral se refere.

O desfile em si não é um espetáculo teatral, porém é possível "ler" teatralidade em todo o desfile, em algumas escolas de forma mais evidente, em outras de forma sutil, mas sempre presente. A natureza mimética empreendida no desfile nos permite, enquanto espectadores, reconhecer uma intenção interpretativa, ou então lançar sobre o que vemos a teatralidade que nosso olhar cria, a partir do momento que concebe aquele espetáculo como uma grande representação e "semiotiza" tudo que vê. Como, porém, a mímesis é utilizada no desfile? Propõese ser uma cópia, uma tradução ou uma reinvenção da realidade?

\section{A NATUREZA MIMÉTICA}

Diferente de um espetáculo teatral, que normalmente segue um referencial estético único, na maioria dos casos os desfiles das escolas de samba lançam mão de todos os recursos possíveis, bem como de todas as formas poéticas cabíveis para "contar" o enredo. Assim, percebemos que a natureza da mímesis é variável, sendo em alguns setores mais imitativa, compromissada com as representações reais, e em outros mais livre, deixando de traduzir, para reinventar e nos oferecer uma nova percepção, alternativa, sobre o que conhecemos como real. A natureza carnavalizada por si só não se prende às convenções; é próprio do carnaval recriar o mundo, transfigurar as imagens, bagunçar a suposta ordem que acreditamos que a realidade possua. Então, é normal que no desfile carnavalesco, a mímesis se baseie muito mais na "não imitação", na reinvenção, ainda que utilize nossos referenciais da realidade para poder confrontar com a nova imagem que se oferece, e a partir desse confronto perceber a intenção de representação.

Seguindo as categorias propostas por Féral, podemos verificar que se trata, então, de uma mímesis geral, não restrita, ou seja, não se ocupa em representar a realidade, ser plausível e verossímil, mas, sim, contar a história a seu modo através de metáforas e de abstrações. Recria a história, a cidade e as personagens de sua narrativa. E dentro dessa mímesis geral (também chamada por Féral de ativa e produtiva) varia a intensidade do processo mimético, ora apelando para uma figuração mais real, ora apelando para o imaginário, o lúdico.

Em cada setor, em cada ala e alegoria, verificamos diferentes formas de representação, diferentes manipulações e usos da mímesis, sendo esse o motivo por que elegemos pontos do desfile mais teatralizados do que outros. Na verdade, todo o desfile é teatralizado; o que se altera é nossa percepção. Dessa for- 
ma, quem desfila prevê a leitura do espectador e manipula os recursos "cênicos" para estabelecer com o público a relação teatral, rompendo a fronteira da realidade e adentrando num mundo lúdico e festivo, em que os parâmetros do real são deixados de lado até que o desfile acabe, toda a escola passe, e, como num tombo, "voltemos" à realidade, percebendo agora o quanto ela é pouco colorida e pulsante.

Então, podemos dizer que é a presença da mímesis (imitativa ou não) que determina a presença da teatralidade no desfile. Pois se a teatralidade está nos olhos de quem vê, ela só está presente quando o público identifica uma natureza mimética, a intenção de uma representação. Observando o desfile percebemos a teatralidade pulsar em alguns momentos e se esconder em outros, e verificamos que isso se deve à intenção mimética colocada nas alegorias, nas fantasias ou nas performances dos próprios integrantes da escola, construindo um "ambiente representativo".

As fantasias em geral são de caráter lúdico, pequenas alegorias, portadoras de um significado muitas vezes abstrato, outras figurativo. Chamo atenção para a vestimenta porque seu funcionamento mimético difere do que se refere ao restante dos elementos do desfile: quanto mais subjetiva, abstrata, lúdica for a fantasia, mais se torna difícil a leitura da teatralidade, devido à falta do reconhecimento da mímesis, do referencial real. Nesse caso da falta de reconhecimento, a teatralidade depende de que o espectador crie o espaço fictício em sua mente não necessariamente a partir da intenção concreta do artista, mas do que, como espectador, imagina. Por depender mais da imaginação do espectador do que da materialidade da expressão cênica, a leitura se torna mais subjetiva, e a teatralidade menos evidente, embora ainda legível.

Portanto, quanto mais figurativa, quanto mais fácil a leitura de seu significado por parte do público, maior a possibilidade de leitura da teatralidade. Quanto mais as fantasias se aproximam de figurinos, mais explicitam sua duplicidade e evidenciam o caráter teatral, representativo. Uma ala cuja fantasia seja para o público apenas luxuosa, bonita e chamativa, pode suscitar a criação da teatralidade, mas por se basear mais na visualidade e menos na intenção cênica, é mais comum que o espectador apenas passe seu olhar rapidamente, identificando, às vezes, o que a fantasia significa, mas não Ihe atribuindo necessariamente caráter teatral, apenas reconhecendo o significado em sua plasticidade. A teatralidade é mais facilmente concretizada pelo espectador ao ver passar uma ala cuja fantasia remeta a algo que o público consegue identificar de imediato, compreendendo seu significado no contexto do enredo, pois verifica a intenção de representar algo e não apenas tecidos, plumas e brilhos. Nas "fantasias figurinos", que 
imediatamente identificam uma personagem ou um tipo representado, o público logo percebe a teatralidade, pois apresentam claramente a duplicidade. Através delas o espectador vê o ator e seu personagem, e não só o integrante da escola pulando o carnaval.

É importante, contudo, perceber que o funcionamento expressivo das fantasias também está diretamente ligado às performances dos integrantes da escola, que podem ser diferenciadas dependendo do setor do desfile. O uso e a manipulação da mímesis depende diretamente da intenção do integrante em representar, da consciência ou não do caráter imitativo de seu corpo e de como se relaciona com a fantasia e objetos do desfile. Em muitas alas, os integrantes simplesmente vestem a fantasia para brincar o carnaval, desfilam despreocupadamente, remetendo-se apenas ao caráter festivo do evento, e não ao dramático. Muitos compram a fantasia por ser a que acharam mais bonita e vistosa, outros por ser mais leve e fácil de portar, e ainda há os que vestem a fantasia que foi possível, a que sobrou no disputado mercado do carnaval.

O que quero observar é que há os integrantes que nem sequer conhecem o significado de sua fantasia no enredo, pois ela é apenas um pretexto, um ingresso, para desfilar no sambódromo. Esses, então, desfilam dançando e cantando o enredo como se estivessem num bloco de carnaval; a diferença aqui é que têm consciência de que são vistos por milhares de pessoas nas arquibancadas. Essa consciência de ser observado faz com que todo o gestual e a energia sejam modificados, pois a preocupação com o olhar do outro lhes impõe exposição maior, ostentação de seu próprio corpo e presença. Portanto, "interpretam", embora se trate mais de uma interpretação social, ou seja, a vivência passageira de um status de visibilidade social. Durante a travessia da avenida cada integrante quer ser observado, admirado, quer destacar-se do coletivo, para isso utiliza-se da dança e do jogo de olhares com o público para atrair a atenção sobre si. Nesse sentido, seu gestual não é necessariamente mimético, pois trata-se mais de exibição do que de interpretação.

Porém, até mesmo esses integrantes menos compromissados com o caráter representativo do desfile, pelo fato de estabelecerem um vínculo com o espectador, podendo fazer parte do enquadramento deste em sua leitura da obra, têm significado no enredo, pois estão dentro de um contexto representativo, imaginário. Nesse caso, se a teatralidade é lida pelo espectador, é porque ele lançou sobre o objeto esse valor, e não porque o objeto em si provocou intencionalmente essa perspectiva teatral, por mais que tenha atraído atenção através da alegria com que dança e canta o samba-enredo, mobilizando as atenções do público. 
Por outro lado, há alas cuja fantasia insinua uma personagem por ser mais figurativa e menos abstrata, como vimos, em que, dependendo do comportamento do integrante na avenida, o modo de portar a fantasia e com ela se relacionar, algum caráter mimético pode ser reconhecido. Uma tentativa de brincar com a possível personagem pode criar não uma interpretação, mas um estado de interpretação que, se reconhecido pelo público, pode ser lido como teatralidade. Nesse caso, o espectador lê um conjunto de recursos que o leva a conceber algo como teatral. Esse conjunto é composto por elementos que vão desde a fantasia até o gestual do integrante que, apropriando-se da ideia da roupa que veste, produz gestualidade mimética e referenciada ao tema que traz na vestimenta. Dessa forma induz e prevê o olhar do espectador, criando ficcionalidade consciente. Uma ala cujos componentes estejam fantasiados, por exemplo, de camponeses, com ferramentas agrícolas como adereços, a partir do momento que os desfilantes brincam com o adereço que têm em mãos, simulando seu uso comum, cria um estado representativo, passivo de leitura ficcional.

No entanto, a intenção de teatralidade é concretizada pelos criadores do espetáculo na construção de momentos nitidamente armados para funcionar teatralmente. É o caso do uso de personagens individualizadas no enredo, que são facilmente reconhecíveis pelo público e que atuam na avenida com movimentos marcados, às vezes, até mesmo coreografados, evidenciando em todo o seu gestual corpóreo uma interpretação codificada, prontamente percebida pelo espectador como teatral. Além disso, nos últimos anos vem-se tornando cada vez mais comum no carnaval, o uso de alas coreografadas ${ }^{11}$ ou marcadas, em pequenas encenações e até mesmo dramatizações de determinados momentos do enredo. Nesse caso, a intenção mimética é nítida, o espectador reconhece de imediato o caráter espetacular, representativo e, consequentemente, lê a teatralidade. Porém, esse reconhecimento sempre dependerá de até que ponto o espectador compartilha dos códigos estéticos presentes no que vê.

\section{PERSONAGENS/TIPOS/ALEGORIAS/FIGURAS}

Em busca do efeito cênico, do espetacular, a performance interpretativa dos integrantes das escolas de samba pode variar (conforme mencionei) dependendo também da natureza mimética empreendida em cada ala ou fantasia da escola. É justamente no caráter mimético que se reconhece a natureza ficcional dos sujeitos representados na avenida. Num desfile podemos identificar personagens do enredo, como também é possível identificar tipos, mas são as alegorias e as figuras os mais recorrentes recursos de representação. Há diferença substancial entre o que se denomina personagem, tipo, alegoria e figura. A esse respei- 
to, Ryngaert (1996, p. 127). afirma que "se admitimos as diferenças que existem entre uma alegoria medieval (a caridade) e um tipo da Commedia dell'arte (Arlequim) não podemos de repente confundi-los sob o mesmo rótulo de personagem". Portanto, utilizarei as seguintes concepções:

a) Alegoria - representa, corporifica uma abstração ou um objeto inanimado, criando uma espécie de "personagem revestida de atributos e de propriedades bem definidos (a foice da Morte, por exemplo)" (PAVIS, 1999, p. 11).

b) Tipos - são esboços de personagens arquetípicas, de rápido reconhecimento, sendo na maioria personagens icônicas de um sujeito social específico - como o caso do tipo brasileiro/carioca, o malandro - dentro de um contexto sociocultural determinado. Conforme define Pavis (p. 410), é uma "personagem convencional que possui características físicas, fisiológicas ou morais comuns conhecidas de antemão pelo público e constantes durante toda a peça". O tipo é uma generalização, uma ampliação que elimina a ideia de individualidade em favor de uma simplificação em seu traço compositivo.

c) Personagem - é uma "ilusão de pessoa humana", segundo Pavis (1999). Tendo traços de personalidade, é uma construção mais complexa, individualizada, que comporta uma gama de características em sua composição que a tornam "única".

d) Figuras - são as personagens "rasas", ou seja, que têm construção mais visual, que as remete a um grupo social, histórico, específico, mas que não têm construção individualizada, subjetivada e não é de domínio comum. A seu respeito, Pavis (p. 167) registra que "é uma forma imprecisa que significa mais por sua posição estrutural que por sua natureza interna".

Independentemente de suas naturezas, todas elas se referem à construção de um "sujeito ficcional" (ou de uma "ideia ficcional", no caso das alegorias), que pode ter natureza variada: mitológica, histórica, ou mesmo abstrata. A construção de "sujeitos ficcionais" é fundamental para a teatralidade, pois o público sempre se apoia nesses "sujeitos" para poder "entrar" na ficção, para poder participar.

Dessa forma, nos desfiles das escolas de samba, o uso de personagens, dentro dessa acepção, dificilmente é encontrado. Não há espaço, nesse evento, para subjetivação, construção que vá além de uma caracterização visual, ou seja, nesse espetáculo a personagem só é percebida semanticamente, numa significação global, sem que haja espaço para o discurso. O espectador tem contato muito breve com cada sujeito ficcional que observa, detendo-se em seu visual e, às vezes, em sua performance física, corporal, para identificar a ficcionalidade, sem tempo nem espaço para se fixar na análise individual de cada sujeito. Além dis- 
so, a construção de personagem depende primeiramente do artista, que a cria, se relaciona com o sujeito ficcional para depois externá-lo. No caso dos desfiles, essa preparação do artista não é comum, não havendo estudo, psicologização ou construção detalhada da "personagem" que desfila na avenida.

Mais comum é o uso de alegorias, apresentando-se sob duas formas: abstrata e figurativa. As alegorias abstratas são as que personificam o que há de imaterial, como os sentimentos, as emoções, as entidades mitológicas, etc. Se na Idade Média utilizavam-se as alegorias para tratar do "amor", do "ódio" etc., nos desfiles, aqui analisados, elas aparecem principalmente nas fantasias das alas, em que cada integrante pode representar uma alegoria abstrata, como, por exemplo, a "vida" ou a "morte". Aqui a natureza mimética é menos evidente, posto que não se pode imitar algo que não existe materialmente para ser observado. Dessa forma, um integrante trajado de morte não a interpreta, apenas leva-a na fantasia que veste, dessa forma representando simbolicamente essa alegoria.

Já as alegorias figurativas são as mais utilizadas e comuns nos desfiles de carnaval. São elas que corporificam os objetos e as coisas inanimadas, dando-lhes vida na avenida. Aqui os integrantes representam em suas fantasias esses elementos, fazendo-os serem reconhecidos por suas figurações, algumas vezes identificadas pelo público, outras não, dependendo diretamente do grau de figuração, ilustração, colocado nas fantasias. Da mesma forma que nas alegorias abstratas, a representação mimética torna-se difícil de ser realizada pelos integrantes, por falta de referencial imitativo, como também de ser identificada pelo espectador, que apenas a reconhece na fantasia. Dessa forma, o reconhecimento da teatralidade é proporcional ao poder ilustrativo da fantasia, que realmente remeta ao referencial material a que se propõe.

Os tipos mais comuns e usuais, como, por exemplo, o malandro e a mulata, são assim reconhecidos no contexto carnavalesco por já fazer parte do imaginário coletivo quando o assunto é carnaval. Os malandros são representados no desfile pelos sambistas, e as mulatas pelas passistas (embora seja muito comum ter mulheres brancas como passistas). Outros tipos também são usados, mas seu reconhecimento sempre dependerá do conhecimento prévio do espectador a seu respeito, ou seja, do contexto cultural.

As figuras, como sujeitos ficcionais humanizados, são mais recorrentes no carnaval. Não se constituindo como personagens, são representações de sujeitos sociais, históricos. Aparecem predominantemente nas alas, podendo ser coletivas, como, por exemplo, uma ala de soldados, marinheiros, imigrantes, etc., mas também aparecer em pequenas encenações, destacadas, ganhando caráter individualizado, ainda que não deixem de ser esboços de personalidades. O que que- 
ro enfatizar aqui é que as figuras, entre outras concepções de sujeitos ficcionais nos desfiles, são as que mais apresentam mímesis evidenciada e codificada, sendo figuras que sempre referenciam pessoas e/ou grupos reais, cabendo aqui uma imitação mais concreta, ainda que estilizada, o que Ihe confere a teatralidade.

\section{FUNCIONAMENTO RETÓRICO-SIMBÓLICO}

Os desfiles carnavalescos, em função do enredo, comportam uma narrativa, ainda que fragmentada. Essa narrativa não segue os padrões dramáticos, aristotélicos, em que a noção de ação e reação predomina. Ao contrário, essa narrativa coloca em segundo plano a necessidade de desdobramento do enredo. Sendo fragmentada, as partes individuais podem ser representadas em diversas sequências. Um fragmento do desfile não justifica o outro, nem o desencadeia. Por exemplo, as alas, mesmo colocadas dentro de um contexto do enredo, não seguem uma linha lógica de desencadeamento de ações, não obedecem à ideia de sucessão. Os fragmentos são agrupados segundo temas, tempos históricos, linguagens visuais etc. Dessa forma, a leitura que propõem ao espectador não é linear, de uma história estruturada para ser compreendida, com início, desenrolar e fim. O desenrolar da história do enredo pouco importa, do ponto de vista narrativo. Nos desfiles são de fato criados estados, composições cênicas, estéticas, sobre um tema específico, sem pretensão de se fazer entender logicamente. Porém, apesar da narrativa fragmentada, sempre está implicada a escolha de uma "dramaturgia".

Nessa ação descontínua, fragmentária, são criados quadros dinâmicos sobre os enredos, podendo ser independentes entre si, se olhados individualmente, mas que quando relacionados ao restante ganham uma multiplicidade de significados, que servem a uma possível construção do sentido geral do enredo. Os vários espaços/imagens imbricados, justapostos, mesmo independentes uns dos outros, se apresentam sincronicamente. Esses quadros dinâmicos têm valores próprios no desfile, suas presenças enriquecem a narrativa, mas suas ausências e substituições por outros não afetariam problematicamente a composição cênica, devido à impossibilidade de uma percepção uniforme e concludente da apresentação. Quanto à possibilidade de narração de um desfile de carnaval, Cavalcanti (2002, p. 18) afirma que:

O enredo funciona parcialmente como princípio organizador da narrativa (...) Não há, entretanto, num desfile unidade ou coerência de sentido que resista por mais que um breve instante. Um desfile corresponde ao esquartejamento visual dos enredos, subdivididos em múltiplos tópicos, que se abrem, por sua vez, em muitos 
outros numa cadeia infindável, ou melhor, que só se fecha por necessidade externa: o tempo de sua apresentação se esgota. Os enredos são assim remendados, triturados, expandidos nos tópicos representados nas alegorias e desdobrados nas fantasias. Tudo se complica ainda mais pois, enquanto visualmente há desdobramento e multiplicação, musicalmente há reforço e repetição.

A infinita possibilidade de enquadramentos, a riqueza visual, o "inebriamento" frente a tantas informações simultâneas são dados justamente por essa abertura narrativa que Cavalcanti refere, por essa possibilidade de multiplicação, pelo desdobramento que o enredo pode sofrer, abrindo infinitas janelas de possíveis sentidos, já que um elemento faz referências a uma gama de outros, e assim sucessivamente. Um tema, seja ele qual for, pode ser muito rico e explorado infinitamente devido a essa abertura da estrutura narrativa, possibilitando liberdade criativa ao carnavalesco para abordá-lo sob diferentes vieses, podendo confrontar livremente a verossimilhança, trazendo referências dos mais diferentes campos, sem que isso soe incoerente. Num mesmo enredo podem ser trazidas informações históricas, míticas, recriações livres de qualquer tema, de uma forma fantasiosa, até mesma absurda, se levarmos em conta a realidade. Assim como um fio puxado traz toda a teia, o desfile vai multiplicando seus significados para o espectador infindavelmente, significados previstos pelos carnavalescos ou nem sequer por eles imaginados.

Portanto, a preocupação com a coerência nos desfiles é deixada em segundo plano, pois o que importa é a ambiguidade presente, a plurivalência e a simultaneidade que o olhar do espectador é convidado a presenciar. Nessa criação de estados cênicos as imagens são tumultuadas, e o espectador para poder captar algo precisa fazer escolhas, limitar seu próprio olhar. Afirma Lehmann (2007, p. 147) ao abordar a recepção no teatro pós-dramático: "torna-se decisivo que o abandono da totalidade não seja pensado como déficit, mas como possibilidade libertadora - de expressão, fantasia e recombinação". Acredito que esse pensamento de Lehmann possa nos servir para avaliar a recepção dos desfiles de carnaval, visto que a estrutura narrativa com que o espectador se depara está mais próxima do pós-dramático do que do dramático, principalmente em função de seu caráter fragmentado e liberto do compromisso com a racionalidade, dando vazão ao imaginário e ao onírico.

Como no teatro pós-dramático, o olhar do espectador no desfile fica indeciso, os signos que Ihe são apresentados não oferecem nenhuma possibilidade de síntese, mas o levam a uma participação ativa de associação, combinação e reformulação do que vê, que dificilmente resultará numa criação fechada de 
sentido. O espectador que procurar entender o desfile em sua completude certamente terá essa ânsia de sentido frustrada e insatisfeita. É certo nesse caso, porém, como observa Lehmann, que cada espectador tem o espetáculo que "merece", pois sempre dependerá de sua disposição a comunicação para que algo realmente ocorra para ele.

O que é criado nos desfiles é um espaço metafórico-simbólico que pretende encaminhar o espectador para a atividade de percepção do que se apresenta e fornecer-lhe, através da estrutura descontínua e da relatividade das mensagens visuais, uma liberdade de criação, de fruição estética, imagética. Nesse espaço metafórico, para ser percebido como tal, são criadas estratégias de "molduragem"12 que sejam capazes de submergir o espectador na contemplação dos detalhes, organizando as informações visuais numa espécie de quadro (tableau). A partir dessa imersão nos dados visuais e cênicos do desfile é que o espectador poderá perceber uma narração, ainda que fragmentada, que comporte um conteúdo histórico ou mesmo temático, por meio das associações estabelecidas.

\section{PAPEL DO ESPECTADOR NA PRODUÇÃO DO SENTIDO}

No século XX a concepção de teatro e o que ele deve suscitar no espectador são marcados pelo pensamento de Antonin Artaud (1896-1948), idealizador de um espetáculo que "atacasse" o espectador, ou melhor, que atacasse seus sentidos, que apelasse para a sensibilidade, antes mesmo da racionalidade, envolvendo-o mediante fortes e variados estímulos que acessassem seus sentidos através das "imagens visuais dinâmicas e alucinantes" (JAVIER, 1998), bem como através dos sons, de seus ritmos e pulsações. Se pensarmos nos desfiles de carnaval e o que eles suscitam, enquanto sensações, e como fazem para suscitar, não será difícil perceber sua capacidade teatral-estética de "atacar o espectador", de ser um ato teatral concreto, espetacular.

Para compreender como se opera a formação do sentido no desfile carnavalesco, utilizo como referencial a concepção quanto à recepção proposta por Marinis (1997), que entende o teatro como um fazer relacional. Um espetáculo não existe, como feito estético, até ser colocado em relação ao espectador. Uma obra é ativada e legitimada na recepção. Um desfile de carnaval só se monta, se constrói no momento de entrar na avenida. Até ali, a escola de samba não havia experimentado a estruturação do desfile, com todas as alas, cada uma em seu lugar do enredo, com os carros alegóricos, com os casais de mestre-sala e portabandeira etc. Nos ensaios gerais na avenida a escola ensaia a evolução e a harmonia $^{13}$ (dois quesitos técnicos fundamentais para um bom desempenho na passarela), porém, sem a presença de todos os integrantes, sem fantasias e carros. 0 
espetáculo em sua totalidade só se materializa na concentração, minutos antes de entrar na avenida. Quem desfila não tem a noção do todo, visto que não viu as demais alas, os carros alegóricos, ou então se os viu, estavam no barracão da escola ou na concentração, não na avenida, repletos de pessoas e luzes. E, mais importante, nunca viu os carros em relação com os demais elementos do desfile, no conjunto da obra. Isso se evidencia no depoimento do jornalista Zeca Camargo, publicado em sua coluna na internet, após desfilar na Escola de Samba Viradouro, em 2007:

Ao encontrar pessoas no camarote que visitei, e contar que tinha acabado de sair na Viradouro, recebia uma manifestação de puro êxtase. Era sempre um comentário do tipo: “Nossa, eu nunca vi nada igual!" ou "Não dava pra acreditar no que eu tava vendo...". Eu mesmo ouvia tudo sem noção de como tinha sido o desfile como um todo - algo impossível para alguém que está ali na passarela.

Dessa forma, quem desfila não terá noção do todo, apenas do fragmento do qual fez parte. Quem primeiro vê o conjunto é o espectador. Assim, o desfile, de fato, só existe como feito estético quando colocado em relação ao espectador, até mesmo para seus integrantes. Mesmo o espectador não consegue ver o todo de imediato, visto que cerca de três mil pessoas passam por ele, distribuídas em alas, carros alegóricos, de uma forma que seu olhar só consegue captar enquadramentos fragmentados, nunca todo o desfile. A ideia de conjunto se dá através da captação de cada fragmento e da relação entre um e outro. Além disso, a riqueza visual é tal, que torna impossível apreender cada detalhe do desfile, sendo necessário eleger para onde olhar, o que enquadrar, deixando de lado outras informações. Nesse sentido, na percepção do espectador, como afirma Massa $(2007$, p. 31) ao se referir à recepção teatral, "é mais fácil reconhecer o distinto do que aquilo que se mostra como redundante", ou seja, no desfile, o espectador é atraído pelo que se destaca no conjunto. Por isso, as alas encenadas, coreografadas, marcadas, chamam tanta atenção, pois ali o espectador é surpreendido, fica na expectativa do desenrolar da performance, diferente das alas sem marcação, cujos integrantes dançam livremente. Neste último caso o olhar do espectador passará mais rapidamente, visto que já sabe o que esperar, indo em busca de uma atitude diferente, de uma performance distinta e nova que o surpreenda.

Se Barthes afirmou que o teatro é "una especie de máquina cibernética que envia varios mensajes simultanemente" (apud MARINIS, 1997, p. 21), o que podemos dizer de um desfile carnavalesco? A estrutura narrativa fragmentada, a riqueza visual e os inúmeros elementos que, nos desfiles, passam pela vista do espectador, fornecem uma multiplicidade de enquadramentos possíveis. O pú- 
blico, parado, com lugar definido na arquibancada, vê passar em sua frente um espetáculo móvel, que a ele se exibe. Se tivesse a liberdade de se movimentar, acompanhar as alas, os carros, perderia todos os demais elementos do espetáculo. O desfile, através de diversos recursos visuais e sonoros, lança mão de uma "infinidade de elementos que remetem simultaneamente a muitos e imprevistos significados" (CAVALCANTI, 1999, p. 50).

A natureza do desfile é metafórica, sempre remetendo a algo. Adotando a perspectiva de Maffesoli (1998), poderíamos sugerir que o desfile é polissêmico, ou seja, não possui um sentido determinado, mas sentidos que são postos à prova e vividos à medida que vão surgindo. Os elementos expressivos são quase sempre polivalentes, apresentando uma multiplicidade de significados e interpretações possíveis que caracterizam o desfile como obra aberta à espera do espectador para significar. Porém, esse "significar" não encontra parâmetros na racionalidade, na estruturação lógica e linear de uma narrativa. Nesse caso, o racionalismo é "inapto para perceber, ainda mais apreender, o aspecto denso, imagético, simbólico, da experiência vivida” (MAFFESOLI, 1998, p. 27).

O processo cognitivo, nesse espetáculo, se opera pela percepção sensível, estética, utilizando-se da sensorialidade e emotividade do espectador para criar um sentido ou uma gama infinita de sentidos possíveis e, dessa forma, ser capaz de reconhecer a teatralidade presente. Demeulenaere (apud MASSA, 2007, p. 73) "nota que a sensação, percepção, sentimento e razão são aspectos da cognição (...) Para ele, a percepção tem sempre uma dimensão cognitiva, na medida em que implica operações complexas de reconhecimento". Não é preciso nem, muito menos, possível entender cada parte do desfile, sua relação direta com o enredo, pois o processo cognitivo ocorre por meio do jogo entre imaginação e entendimento. O prazer reside, justamente, no reconhecimento desse jogo, na identificação de um referente conhecido em meio a tantas imagens aparentemente desconexas, e é aqui que reside a teatralidade do espetáculo carnavalesco. A percepção desses elementos faz relações e chega a possíveis sentidos por meio dos arranjos, combinações feitas por vias sensório-cognitivas.

Marinis (1997, p. 32) defende a ideia de que toda análise espetacular pressupõe três aspectos: estético, semântico e emotivo. Extremamente relacionados entre si, esses aspectos são também, contudo, independentes, podendo um funcionar em contraposição a outro, sendo possível, que "nos impacte positivamente um espetáculo cujo significado não resulte claro e viceversa". ${ }^{14}$ Esse é o caso do desfile de carnaval. O público não recebe o espetáculo como uma história à qual ele assiste, mas como várias histórias, situações, que o encantam através da visualidade, da relação com os participantes do desfile, com a sonorida- 
de da bateria e com os jogos de identificação de uma intenção representativa, a teatralidade.

Os desfiles são fortemente marcados pelo simbolismo. Seu arranjo enquanto obra é conotativo. Seus elementos expressivos, as ações, as performances, os objetos, ao ser expostos ao público são inevitavelmente envoltos em muitas metáforas. Esses elementos conotativos, ao entrar em contato com o conhecimento enciclopédico e ideológico do espectador, criam inúmeros significados, e são esses significados que contribuirão para que o espectador estabeleça um sentido global para o desfile. Mesmo que passe por ele inúmeras alas em que ele não identifique nenhuma teatralidade, ou então, nenhuma referência ao enredo, isso não atrapalhará sua leitura. No desfile o espectador elege automaticamente o que entende, criando relações, como também elege o que não entende, mas nem por isso deixa de fruir o quê vê, nem de se afetar.

Nesse sentido, o espectador é o que Marinis (1997) chama de um sujeito dramatúrgico, aquele que participa ativamente do espetáculo, construindo, a partir de sua percepção e suas referências, o sentido da obra. É um coprodutor do espetáculo que autonomamente segue as pistas dos elementos conotativos, cria lógicas pessoais, se envolve imageticamente com o que vê e ouve, construindo assim um espetáculo único, que apenas ele testemunhou, visto que esse processo é individual e para cada espectador há um espetáculo distinto. As pistas dadas no espetáculo, os elemento destacados, os momentos altos de grande espetacularidade tentam de alguma forma manipular o olhar do espectador mediante determinadas estratégias que seduzem, persuadem e induzem no espectador determinadas percepções e reações intelectuais e emocionais. Pode-se então, na criação desses elementos de destaque e insinuação, prever o olhar do espectador. Mas sempre restarão espaços vazios, indeterminados, diante dos quais ele elaborará seu próprio ponto de vista, seguindo ou ignorando as indicações do desfile. Para cada espectador, o desfile é o resultado de suas percepções, de como ressoaram, como criaram reações emocionais e sensoriais.

Assim, podemos afirmar que a recepção não é apenas contemplativa, mas também performativa, visto que exige do espectador papel atuante na criação de algum sentido, por meio de uma dialética, uma relação de jogo entre a obra e quem a observa. O desfile esboça um mundo a ser percebido, imaginado e, até mesmo, interpretado pelo espectador. E é nesse empenho em imaginar que reside a performatividade na recepção; ao ser autor de algo novo, com significação original, o espectador é chamado à ação, à atividade criadora.

Em atitude de relação horizontal com o público, o desfile é fundamentalmente uma obra aberta não só enquanto significação, mas, sobretudo, aberta a 
todos os níveis de olhar, atendendo a todos os "padrões intelectuais". Não exige pré-requisitos intelectuais para que construa um significado, pois não exige nada do espectador além do que ele já possua. Uma pessoa iniciada no assunto tratado no enredo terá leitura diferente da que fará alguém que o desconheça, mas isso não determinará bloqueio, barreira intransponível na recepção; ao contrário, o olhar simplesmente se voltará para outro enfoque.

\section{REFERÊNCIAS BIBLIOGRÁFICAS}

CAMARGO, Zeca. Paulo Barros e a metamorfose. Disponível em: <http://colunas.g1.com.br/zecacamargo/2007/02/26/paulo-barros-e-a-metamorfose/>. Acessado em 01.09.2009.

CANCLINI, Nestor García. A socialização da arte - teorias e práticas na AméricaLatina. São Paulo: Cultrix, 1980.

CAVALCANTI, Maria Laura Viveiros de Castro. Os sentidos no espetáculo. Revista de Antropologia. São Paulo, v. 45 n. 1, 2002.

. O rito e o tempo: ensaios sobre o carnaval. Rio de Janeiro: Civilização Brasileira, 1999.

FÉRAL, Josette. Teatro: teoria y practica, más allá de las fronteras. Buenos Aires: Editorial Galerna, 2004.

. Acerca de la teatralidad. Buenos Aires: Nueva Generación, 2003.

ISER, Wolfgang. Teoria da ficção. Rio de Janeiro: UERJ, 1999.

JAVIER, Francisco. El espacio escénico como sistema significante. Buenos Aires: Leviatan, 1998.

LEHMANN, Hans-Thies. Teatro pós-dramático. São Paulo: Cosac Naify, 2007.

MAFFESOLI, Michel. Elogio da razão sensível. Rio de Janeiro: Vozes, 1998.

MARINIS, Marco de. Comprender el teatro - lineamientos de un nueva teatrología. Buenos Aires: Editorial Galerna, 1997.

MASSA, Clóvis Dias. Estética teatral e teoria da recepção. Primeiro Concurso Nacional de Monografias - Prêmio Gerd Borheim. Vol. III. Porto Alegre: Secretaria Municipal de Cultura, 2007.

NASPOLINI, Marisa. O grotesco em Meierhold: princípios para criação de uma nova teatralidade. Urdimento. Revista de Estudos Pós-Graduados em Artes Cênicas. Florianópolis, v. 1, n. 7, p. 49-56, 2005.

PAVIS, Patrice. Dicionário de teatro. São Paulo: Perspectiva, 1999.

RYNGAERT, Jean-Pierre. Introdução à análise do teatro. São Paulo: Martins Fontes, 1996.

SCHECHNER, Richard. Performance - teoría y practices interculturales. Buenos Aires: Libros del Rojas, 2000.

UBERSFELD, Anne. Para ler o teatro. São Paulo: Perspectiva, 2005. 
VALENÇA, Raquel; VALENÇA, Suetônio Soares. Serra, Serrinha, Serrano: Império do Samba. Rio de Janeiro: José Olympio, 1981.

\section{NOTAS}

1 Acervo da Divisão de Música da Funarte, no Rio de Janeiro.

2 Blocos de carnaval de rua organizados por grandes sociedades carnavalescas que brincavam pelas ruas da cidade do Rio de Janeiro desde meados do século XIX, já apresentando alguns elementos e características que iriam, na década de 1930, resultar na criação das escolas de samba nos morros cariocas e posteriormente, na concepção de desfile que conhecemos hoje.

3 "Meyerhold, quiere, es que el teatro no sea tautológico con la realidad, que no sea redundante. Quiere enfatizar su autonomía y, por lo tanto, su especificidad. El teatro debe desarrollar su propia forma, tiene que convertirse en un arte propio. Es por eso que Meyerhold habla de un teatro teatral (...) el teatro teatral se opone al realismo (...) Según él, hay una teatralidad falsa, la que intenta copiar a la realidad. Por el contrario, él destaca la necesidad de una teatralidad absoluta."

4 "Salir de una estructura binaria, donde las palabras se oponen como una dicotomía (...) teatralidade en un lado y realidad en el outro."

5 "deconstruye, decodifica y construye un objeto que el sujeto mira".

6 "Un comportamiento juzgado muy teatral en una cultura no lo es necesariamente en otra."

7 Quando a palavra performance for citada no decorrer do texto não estarei me referindo ao conceito de performance art, mas sim ao significado da palavra, segundo o dicionário, que se refere ao ato de desempenhar algo. Da mesma forma, quando usar performer, estarei me referindo àquele que desempenha uma ação.

8 "en el actor un juego de fricciones entre códigos y flujos, entre simbólico y semiótico, entre caos y orden con los cuales el actor actúa".

9 De Marinis (1997), utiliza a expressão texto espetacular para referir-se ao espetáculo propriamente dito, o texto da cena, como um material explicativo do funcionamento concreto dos fenômenos observados. Féral (2004), diz que o texto espetacular engloba todos os componentes do espetáculo, desde o texto propriamente dito (dramatúrgico ou não), o texto performático (partitura dos atores, dos efeitos de luz, som e cenográficos), até os elementos visuais (como cenários, caracterização, cores, etc.). Diferente do texto dramatúrgico, o texto espetacular é a escritura do que ocorre na representação, pois essa representação dispõe de um conjunto de elementos de análise próprios, independentes dos elementos da dramaturgia. 
10 "si el espacio potencial del actor y el del espectador no se encuentran, si no se reconecen no hay teatro".

11 Alas coreografadas não são invenção contemporânea; sempre houve, desde os ranchos e cordões. Como tendência estética, porém, nos últimos anos vêm sendo cada vez mais utilizadas como recurso cênico.

12 Termo utilizado por Lehmann (2007) para designar o espaço enquadrado pelo olhar do espectador.

130 quesito Evolução diz respeito à progressão da dança de acordo com o ritmo do samba-enredo, enquanto o quesito Harmonia é o entrosamento do ritmo do samba com o canto da escola.

14 "nos impacte positivamente un espetáculo cuyo significado no resulte claro y viceversa".

Ana Luiza da Luz é atriz, diretora, dramaturga, iluminadora e professora graduada em teatro pela Universidade do Estado de Santa Catarina.

Recebido em: 27/07/2012

Aceito em: 05/08/2012 